Teologia i Moralność, volumen 16(2021), numer 2(30)

doi: 10.14746/TIM.2021.30.2.3

ORCID: 0000-0002-3122-8230

MACIEJ OLCZYK

Uniwersytet im. Adama Mickiewicza w Poznaniu

Wydział Teologiczny

\title{
Naturalna regulacja poczęć wyrazem odpowiedzialnego rodzicielstwa. Interdyscyplinarna argumentacja o. Karola Meissnera w Memoriale Krakowskim
}

\section{Wstęp}

Zagadnienie antykoncepcji, które od czasu do czasu powraca w debacie społecznej i wewnątrzkościelnej, jest problemem bardzo złożonym i wieloaspektowym, dotyczącym intymnej sfery ludzkiego życia. Intymność tego zagadnienia nie oznacza jednak jego prywatności, gdyż skutki stosowania lub niestosowania antykoncepcji mają brzemienne konsekwencje społeczne. Pomimo współczesnych trendów banalizujących to zagadnienie, Kościół katolicki niezmiennie podkreśla jego powagę. Ujawnia się ona tym wyraźniej, im bardziej człowiek idący za Chrystusem odkrywa znaczenie Bożej mądrości i miłości wpisanych w prawo moralne oraz w porządek stworzenia. To właśnie Boża mądrość i miłość oświeca i porusza chrześcijanina do nieustannego rozwoju, aby dążył „do miary wielkości według Pełni Chrystusa” (Ef 4,13). Dla integralnego rozwoju osoby konieczne jest przyjęcie i zaakceptowanie tak porządku stworzenia (ład i celowość), jak i daru zbawienia (udział w Boskiej naturze). Droga ta wiąże się z trudem rozeznania oraz wysiłkiem podążania „ku górze” w obszarze decyzji moralnych potwierdzających Bożą mądrość i miłość. W tej perspektywie możemy lepiej zrozumieć, dlaczego Kościół opowiada się za naturalną regulacją poczęć, widząc $\mathrm{w}$ niej wyraz odpowiedzialnego rodzicielstwa szanującego Boży ład stworzenia i ekonomię zbawienia. Chrześcijanie wierzą, że przez współpracę z Bożą łaską człowiek może przekraczać siebie i wzrastać. 
Dotyczy to wszystkich wymiarów życia - w tym także ludzkiej płciowości, będącej dla człowieka darem i zadaniem. Przemiana i pokonywanie ludzkich słabości wpisane są ostatecznie w naturę dążenia do świętości, do której powołani są wszyscy wierzący w Chrystusa (por. Franciszek 2018, 10-32).

Dokonanie wyboru pomiędzy antykoncepcją a naturalną regulacją poczęć jest problemem zarówno osobistym, jak i społecznym, powiązanym ze światem ludzkich przekonań na temat spraw życiowo najdonioślejszych: miłości, sensu płciowości, przekazywania życia. Posiada także aspekty etyczne wpisane w drogę ludzkiego rozwoju i chrześcijańskiego powołania. Wszystkie te wymiary nie były obce autorom powstałego przed przeszło 50 laty $\mathrm{Me}$ morialu Krakowskiego ${ }^{1}$, dokumentu zawierającego bogatą interdyscyplinarną argumentację na rzecz odpowiedzialnego rodzicielstwa wyrażającego się w naturalnej regulacji poczęć. Wartością tego dokumentu była i jest po dzień dzisiejszy nie tylko jego interdyscyplinarność, ale także wskazanie zalet proponowanej alternatywy dla działań antykoncepcyjnych, za którą przemawiają wyłożone w dokumencie argumenty teologiczne, etyczne oraz medyczne. Podkreśla się, że Memoriał odegrał istotną rolę w debacie poprzedzającej opublikowanie encykliki Humanae vitae, dostarczając Pawłowi VI cennego materiału o charakterze antropologicznym i teologicznym (Dziuba 1999, 42).W ostatnich latach powraca się do tego wątku, przypominając ów polski wkład w kształtowanie się nauczania Kościoła katolickiego na temat antykoncepcji (Mielec 2013; Gałuszka 2018).

Wpisując się w ten nurt, niniejszy artykuł przybliża treść refleksji medyczno-etycznej, jaką przeprowadził w Memoriale Krakowskim lekarz, znawca psychologii płciowości, a zarazem teolog i etyk, o. Karol Meissner OSB. Przygotowana przez niego analiza nie straciła nic ze swej aktualności, co więcej, może posłużyć współcześnie jako wzór budowania argumentacji promującej prozdrowotne metody naturalnej regulacji poczęć jako atrakcyjnej alternatywy dla szkodliwej moralnie, duchowo i fizycznie antykoncepcji. W oparciu o teksty autorstwa K. Meissnera, zawarte w Memoriale, zostanie najpierw przybliżona istota odpowiedzialnego rodzicielstwa (1) i powiązane z nią wymogi moralne (2). Argumenty przemawiające za godziwością naturalnej regulacji poczęć i niemoralnym charakterem antykoncepcji ujawniają się wyraźnie w kontekście rozważań nad fenomenem mowy ludzkiego ciała (3) oraz zna-

\footnotetext{
${ }^{1}$ Dokument nazywany Memoriałem Krakowskim (1968) składa się z pięciu części, które wyszły spod pióra różnych autorów. Każdą z tych części traktuję jako oddzielny artykuł opatrzony własnym tytułem i zamieszczony w dziele zbiorowym. Źródłem dla niniejszego artykułu jest tekst Memoriału opublikowany z inicjatywy o. Karola Meissnera w 2012 r. w formie książki: Memoriat Krakowski. Uzasadnienie katolickiej nauki tyczącej podstaw moralnych życia matżeńskiego (Kraków 1968) oraz Wprowadzenie do encykliki „Humanae vitae” (Kraków 1969), red. Barbara Sadowska. Poznań: BONAMI.
} 
czeniem respektowania twórczej harmonii porządku naturalnego i nadprzyrodzonego w osobowym rozwoju człowieka (4).

\section{Odpowiedzialne rodzicielstwo we wspólnocie małżeńskiej}

Niewątpliwą zaletą refleksji K. Meissnera jest osadzenie problemu regulacji poczęć w pozytywnej perspektywie odpowiedzialnego rodzicielstwa. Zrozumienie bowiem moralnego zła antykoncepcji staje się w pełni możliwe tylko w kontekście nakreślenia pozytywnego obrazu godności osoby, dostrzeżenia sensu płciowości i jej funkcji, a także odkrycia powołania mężczyzny i kobiety, znaczenia ich wzajemnej relacji miłości i intymności. Stąd już w pierwszym akapicie swoich rozważań Meissner odwołuje się do zamysłu Bożego względem małżeństwa i rodziny, którego integralną częścią jest zadanie przekazywania życia i wychowania dzieci (por. Rdz 1,26-28). Właściwe wypełnianie tego zadania, czyli zgodnie z planem Bożym, oznacza roztropną ocenę sytuacji oraz - gdy zajdzie taka potrzeba - odpowiedzialną decyzję dotyczącą liczby dzieci, jaką rodzice mogą przyjąć i wychować. „Ilość dzieci, którym małżeństwo przekaże życie, nie może być pozostawiona przypadkowi" (Meissner 2012b, 34). Ze względu na doniosłość samego aktu prokreacyjnego i godności osobowej tak małżonków, jak i powoływanego do istnienia nowego człowieka, działanie takie powinno być wynikiem świadomej, odpowiedzialnej decyzji ${ }^{2}$.

Odpowiedzialne podjęcie decyzji o ilości dzieci w rodzinie uwzględnić powinno następujące czynniki:

a) Kontekst wiary i ufności pokładanej w Bogu - przez co rozumie się, że małżonkowie są świadomi powołania, jakie otrzymali od Boga. Oznacza to, że rozwiązując życiowe problemy, chrześcijańscy małżonkowie pytają, ,jak Bóg widzi wykonywanie moich zadań, w mojej sytuacji życiowej?” (Meissner 2012b, 43). Powinni pamiętać i ufać, że kochający Bóg pomoże im w wypełnieniu zadań rozpoznanych w prawym sumieniu.

b) Przyjęcie postawy wielkoduszności i gotowości do pewnych ofiar. Urodzenie $\mathrm{i}$ wychowanie dzieci przynosi z jednej strony wiele radości i satysfakcji, ale z drugiej jest okupione często licznymi wyrzeczeniami i trudami. Chrześcijańscy rodzice nie powinni zapominać, że w zadaniach rodzicielskich nie są zostawieni sami sobie, lecz wspiera ich sam Chrystus oraz Jego Kościół. Meissner przypomniał w tym kontekście słowa Jezusa utożsamiającego się z przyjmowanymi dziećmi: „Kto przyjmuje jedno z tych dzieci w imię moje, Mnie przyjmuje" (Mk 9,37) (por. Meissner 2012b, 44).

\footnotetext{
${ }^{2}$ K. Meissner powołuje się w tym miejscu na nauczanie Soboru Watykańskiego II oraz Pawła VI z encykliki Populorum progressio.
} 
c) Wspólne stanowisko małżonków. Decyzja o regulacji poczęć powinna być owocem dialogu miłości męża i żony. Wynika to z natury ich związku, przez który stali się wspólnotą osób - osób równych w godności i prawach. Małżonkowie są za siebie wzajemnie odpowiedzialni, a wspólna misja przekazania życia domaga się razem podejmowanych decyzji w zakresie regulacji poczęć. Tak, jak za życie i wychowanie dziecka odpowiadają obydwoje rodzice, tak i za jego poczęcie - lub jego ewentualne odroczenie - razem są odpowiedzialni (por. Meissner 2012b, 45).

d) Uzasadnione motywy, które powinny wypływać ze względów lekarskich (troska o zdrowie), dla dobra dzieci (już urodzonych i planowanych) oraz ze względów ekonomicznych (sytuacja materialna i duchowa rodziny) (por. Pius XII 1951, 835-854). Należy uwzględnić tu również dobro wspólnoty, do jakiej małżonkowie należą (rodziny, społeczeństwa, Kościoła) oraz warunki i okoliczności czasów, w jakich przyszło im żyć. Karol Meissner zauważa, że „wymienione tutaj elementy, które mają się stać podstawą ważnej w życiu małżeńskim decyzji, mogą dostarczyć motywów nie tylko ograniczania ilości dzieci, ale przeciwnie, mogą dostarczyć motywów dla świadomego i dobrowolnego rodzicielstwa" (Meissner 2012b, 35).

e) Wybrany sposób regulacji poczęć nie powinien stać w sprzeczności z prawem Bożym wyjaśnianym przez Kościół. Oznacza to, że odpowiedzialni rodzice, realizując powzięty plan regulacji poczęć, nie powinni sięgać po środki sprzeczne z Bożą mądrością i miłością. Nie wystarczą jedynie dobre intencje - Pan Bóg pragnie przede wszystkim dobrych czynów (por. Pius XII 1952, 69-78). A zatem dobry „czyn ludzki powinien odpowiadać stwórczemu planowi Boga, wyrażonemu w takiej, a nie innej strukturze człowieka i właściwych mu działań" (Meissner 2012b, 35-36). Nie można zatem uznać za dobre, a więc i moralnie dozwolone, działania, które ze swej natury niszczy porządek stworzony przez Boga, dezintegrując przebieg naturalnych i zdrowych czynności organizmu, jak to ma miejsce w przypadku stosowania antykoncepcji.

\section{Sformulowanie wymagań moralnych}

Nakreślona powyżej koncepcja odpowiedzialnego rodzicielstwa pozwala na wyłonienie zasadniczych wymagań moralnych, w świetle których będzie można dalej dokonać etycznej oceny postaw bezpośrednio związanych z ludzką prokreacją. Pewien przedsmak tych wymagań został zarysowany już w ostatnim punkcie wymienionych powyżej wymiarów odpowiedzialnego rodzicielstwa. Karol Meissner precyzuje je dokładniej w dalszej części przeprowadzonych analiz. Jego zdaniem w ocenie moralnej sposobu regulacji poczęć 
uwzględnić należy dwa rodzaje wymagań stawianych małżonkom: z jednej strony przez godność osoby, a z drugiej przez sens ludzkiego życia płciowego (Meissner 2012b, 36). Spójrzmy zatem na te wymagania w kolejności zaproponowanej przez benedyktyńskiego lekarza, teologa i etyka.

\section{a) Wymagania stawiane przez godność osoby}

Wymaganie to nawiązuje do równości zachodzącej pomiędzy kobietą i mężczyzną jako osobami ludzkimi. Meissner sformułował je następująco: „W podejmowaniu dzieła regulacji poczęć winna istnieć równość i współmierność wkładu mężczyzny i kobiety" (Meissner 2012b, 36). Korzystając ze swej wiedzy medycznej i praktyki lekarskiej (kontakt z kobietami stosującymi doustne środki antykoncepcyjne oraz wkładki wewnątrzmaciczne), wnioskował logicznie, iż „wywoływanie w ustroju kobiety, a zatem w osobie, zmian uniemożliwiających poczęcie, a zwalniających mężczyznę od odpowiedzialności w działaniu seksualnym, nosi cechy niesprawiedliwości" (Meissner 2012b, 36). Trudno przecenić walor powyższego argumentu. Jest to argument daleki od dyskursu naturalistycznego, przenoszący uwagę w kierunku osobowej relacji zachodzącej pomiędzy kobietą i mężczyzną. Refleksja Karola Meissnera nawiązuje do zasady sprawiedliwości z uwzględnieniem przebiegu procedur antykoncepcyjnych, które z gruntu rzeczy w uprzywilejowanej pozycji stawiają mężczyznę, a kobietę skazują na poddawanie się działaniom zaburzającym jej rytm płodności i szkodliwym dla zdrowia.

W innym miejscu swych rozważań Meissner zauważy, że już niejako z natury ,istnieje nierównoważność biologiczna $\mathrm{w}$ zakresie życia płciowego między mężczyzną a kobietą. Współmierność wkładu w dzieło regulacji poczęć zachodzi tylko wówczas, gdy mężczyzna potrafi włączyć działanie dynamizmu popędowego w rozumne życie, dając wyraz swojej miłości w cielesnym działaniu płciowym tylko wtedy, gdy jest to roztropne. W przeciwnym razie, kobieta będzie niewspółmiernie obciążona życiem płciowym i jego skutkami, albo zgoła stanie się - przynajmniej w pewnym stopniu - przedmiotem użycia ze strony męża" (Meissner 2012a, 55). Antykoncepcja tylko pozornie rozwiązuje wspomnianą nierówność, a w rzeczywistości przyczynia się do jej pogłębienia, zrzucając na kobietę odpowiedzialność tzw. zabezpieczania się przed ciążą i ponoszenie w największym stopniu ewentualnych konsekwencji niepowodzeń w tym zakresie. Mężczyzna z kolei łatwo dyspensuje od wzięcia części swojej odpowiedzialności, co utrwala w nim postawy infantylne i ludyczne, kosztem krzywdy kobiet. 


\section{b) Wymagania stawiane przez sens ludzkiej płciowości}

Moralna ocena antykoncepcji w kontekście odpowiedzialnego rodzicielstwa powinna zdaniem K. Meissnera uwzględniać nie tylko wymagania moralne stawiane przez godność osoby, potwierdzone na kartach Pisma Świętego, ale również brać pod uwagę sens ludzkiej płciowości, jej celowość oraz wewnętrzny logos, jaki nauka (zwłaszcza biologia, medycyna, psychologia) czynią przedmiotem swoich badań. Istotnym wydaje się postawienie pytania o miejsce i znaczenie życia płciowego w strukturze osoby i jej działań (por. Meissner 2012b, 36).

Odpowiadając na to pytanie, Meissner proponuje rozważyć trzy istotne funkcje płci w życiu człowieka: biologiczną funkcję przekazywania życia, funkcję ,pozajednostkową”, mającą wpływ na tworzenie społeczeństwa, oraz funkcję komunikacyjną sprzyjającą budowaniu więzi międzyosobowych (por. Meissner 2012b, 36). Jakie treści kryją się pod tymi określeniami?

Biologiczna funkcja przekazywania życia wpisana jest w naturę narządów rozrodczych kobiety i mężczyzny, stanowiących istotny wyznacznik ludzkiej płciowości. Propagowane współcześnie trendy marginalizujące biologiczny wymiary płci, obecne na przykład w skrajnych nurtach ideologii gender, $\mathrm{z}$ trudną do zrozumienia zaciekłością odrzucają naukowe argumenty płynące $\mathrm{z}$ analizy fizjologii układu rozrodczego, posiadającego swój własny logos, cel i sposób funkcjonowania. Wobec prób nachalnej promocji tej odrealnionej wizji płciowości warto przytoczyć oczywisty argument przywołany przed laty przez benedyktyńskiego etyka i lekarza. Płeć i działanie płciowe, jak wyraził się K. Meissner, „stoją na usługach zdolności przekazywania życia [...] płeć jest właściwością ciała, które wraz z nieśmiertelną duszą tworzy jedność ludzkiej osoby i uczestniczy w jej godności. Toteż płeć, jako właściwość ciała jest właściwością osoby, a działanie płciowe, będąc działaniem cielesnym, jest działaniem w pełni ludzkim" (Meissner 2012b, 36).

Ważnym spostrzeżeniem, jakie pojawia się w Memoriale Krakowskim, jest przypomnienie faktu bardzo podstawowego, dziś często zapominanego lub celowo pomijanego, że pełne urzeczywistnienie wewnętrznego logosu i funkcji układu płciowego dokonać się może tylko i wyłącznie przy udziale dwóch osób zróżnicowanych płciowo: kobiety i mężczyzny. Układ pokarmowy spełnia swoją rolę w każdym pojedynczym człowieku - podobnie oddechowy, krwionośny czy inne układy. Ale układ płciowy ,jest jedynym z układów ustroju, który w prawidłowej swej czynności wymaga współdziałania dwojga osób" (Meissner 2012b, 37). Dana ludziom zdolność przekazywania życia wymaga osobowego spotkania kobiety i mężczyzny, a w ramach tego spotkania dochodzi do pięknego i doniosłego wydarzenia, jakim jest intymne zjednocze- 
nie małżonków. Gest więzi cielesnej realizuje zarazem funkcję zdolności przekazywania życia, której to funkcji żadna z osób nie zrealizuje w pojedynkę.

W ten oto sposób ujawnia się również poza- czy ponad-jednostkowa funkcja ludzkiej płciowości. Popęd płciowy nie tylko sprawia, że dojść może do poczęcia nowej istoty ludzkiej, ale jest on także istotnym czynnikiem więziotwórczym, budującym relacje społeczne. Karol Meissner powie, że popęd płciowy, kierujący osobę do zespolenia płciowego z osobą odmiennej płci, jest dynamizmem ,nadrzędnym w stosunku do potrzeb społecznych osoby ludzkiej. Toteż życie płciowe ma u człowieka określone funkcje pozajednostkowe, a mianowicie międzyosobowe i społeczne" (Meissner 2012b, 37). Spostrzeżenie to dowartościowuje - marginalizowaną zwłaszcza w epoce wybujałego indywidualizmu - społeczną naturę ludzkiej płciowości. Dar płci, z jego bogactwem przeżyć i rozkoszy, nie jest jedynie dobrem indywidualnym, złożem osobistych doznań i indywidualistycznie pojętym źródłem przyjemności, lecz wpisane jest $\mathrm{w}$ jego istotę zadanie budowania wspólnoty osób, poprzez tworzenie więzi międzyludzkich i przekazywanie życia nowym członkom społeczeństwa. Dojrzałe pragnienie urodzenia dziecka oznacza nie tylko zaspokojenie osobistych aspiracji przyszłych rodziców, lecz również uwzględnia wkład małżonków w dobro wspólne społeczeństwa, które dzięki rodzicielstwu zostaje ubogacone kolejnymi istnieniami ludzkimi. Ten specyficzny wkład może być także źródłem dodatkowej satysfakcji rodziców, o ile mają oni dobrze ukształtowany zmysł społeczny (cieszą się z podarowania swoich dzieci wspólnocie, ze wsparcia której przecież sami korzystają lub będą korzystać w przyszłości).

Wreszcie płciowość ludzka ma także funkcję komunikacyjną, poprzez którą ludzie coś sobie wzajemnie wyrażają, dają poznać nieuchwytne bezpośrednio treści duchowe (por. Meissner 2012b, 37). Różne przejawy życia płciowego wpisują się w tzw. mowę ciała dla wyrażenia tego, co ludzi między sobą łączy: służą niewerbalnemu uznaniu wartości drugiej osoby i oznajmieniu jej miłości. Płciowość jest obszarem, w którym posługujemy się specyficznym językiem: językiem gestów i znaków, w które wpisane jest zrozumiałe przesłanie. Tematyka ta została $\mathrm{w}$ ostatnim pięćdziesięcioleciu obszernie rozwinięta w licznych publikacjach, często nawiązujących do myśli Karola Wojtyły i jego ,teologii ciała”,

3 „Teologia ciała” autorstwa Jana Pawła II była stopniowo odsłaniana podczas kolejnych katechez środowych na temat Miłości ludzkiej w planie Bożym wygłoszonych przez Papieża Polaka w latach 1979-1984. Były one duszpasterską adaptacją i rozwinięciem treści zawartych w książce K. Wojtyły Miłość i odpowiedzialność. Zwięzłą charakterystykę „teologii ciała” znajdziemy m.in. w: Kupczak 2013, 37-54; Semen 2008, 46-52. 


\section{Osobowa norma szanująca mowę ciała}

Miłość między kobietą i mężczyzną, gdy osiąga swoje szczyty, wyrażana jest płciowo ,przez zespolenie narządów rozrodczych” (Meissner 2012b, 38), przez zaangażowanie ciała, które komunikuje treści duchowe: zjednoczenie osób i wzajemny dar z siebie w miłości. Oznacza jednocześnie, że miłość ta jest życiodajna, gotowa do dzielenia się życiem i zrodzenia potomstwa. Życie osiągające swe szczyty przez osobową miłość nie może pozostać zamknięte w sobie, bo taka jest natura miłości: do jej istoty należy dawanie życia. Dlatego kochający się małżonkowie dają to życie najpierw sobie nawzajem, a z ich daru rodzi się gotowość do darowania siebie razem dzieciom, które przyjmą do kręgu swojej miłości.

Nasuwa się w tym miejscu pewne duchowe skojarzenie. W chrześcijaństwie życiodajność miłości jest szczególnie uwypuklona w tajemnicy paschalnej. W świetle zmartwychwstania Chrystusa można by obrazowo powiedzieć, że życie ogarnięte wewnątrztrynitarną miłością nie pozwala się zasklepić grobowym głazem, lecz „eksploduje” nieśmiertelnością, o czym przekonuje wielkanocny poranek. Nasuwające się w tym miejscu skojarzenie, choć nie pochodzi wprost od ojca Meissnera, oddaje jednak istotę płodnego charakteru miłości: ona zawsze daje życie i dlatego działania krępujące czy niszczące tą życiodajność intymnego zjednoczenia kłócą się z miłością. Dlatego nie mogą znaleźć uznania nie tylko u osób wierzących, ale także i tych, które rzetelnie analizują na drodze refleksji rozumowej fenomen ludzkiej miłości. Działanie antykoncepcyjne jest w pewnym sensie zataczaniem grobowego głazu na dynamizm życia i miłości.

Powróćmy jednak do rozważań krakowskiego teologa i lekarza. Karol Meissner analizując język zespolenia cielesnego i jego przesłanie, odczytuje w nim pewien fakt podstawowy: akt płciowy powinien być wzajemnym darem i wyrazem miłości małżonków, a ponieważ ,miłość ze swej natury jest skierowana ku przekazywaniu życia i wychowaniu potomstwa, przeto każdy ich stosunek winien być wyrazem ich postawy rodzicielskiej" (Meissner 2012b, 38). I nieco dalej dodaje istotne wyjaśnienie, że choć nie każdy stosunek płciowy u ludzi jest płodny biologicznie, to jednak w każdym zbliżeniu powinien się uzewnętrzniać ów charakter rodzicielski wyrażanej płciowo miłości, gdyż ona $\mathrm{z}$ natury jest nastawiona na zrodzenie i wychowanie potomstwa (por. Meissner 2012b, 38). Miłość jest zawsze życiodajna, ale życiodajność ta nie oznacza konieczności poczęcia dziecka w każdym zbliżeniu intymnym. Innymi słowy, nie każdy stosunek płciowy musi kończyć się poczęciem nowego życia. Jednak w żaden z nich nie wolno ingerować w taki sposób, by odbierać mu jego życiodajność, czyli zaburzać jego prokreacyjną strukturę, celowo go obezpłodniając. „Czynne wkroczenie w strukturę aktu - tłumaczy K. Meissner - 
sprawia, że staje się zniekształcony, co sprawia, że traci wartość jako znak miłości małżeńskiej. Wyraża się w nim wtedy dezintegracja między popędem i miłością. W tych warunkach jest on raczej kierowany dążeniem autoerotycznym i nie jest wprawdzie wyrazem miłości, która powinna obejmować pełnię uczuć i popędu" (Meissner 2012b, 39).

Istotą regulacji poczęć drogą okresowej wstrzemięźliwości jest rezygnacja ze współżycia w okresie płodnym cyklu kobiety i podejmowanie takiego współżycia poza tym czasem, przy jednoczesnej akceptacji życiodajnego charakteru intymnego zbliżenia. Życiodajność w tym przypadku oznacza dzielenie się miłością: darem z siebie w pełni, bez świadomego wykluczania dynamizmu płodności, z dostosowaniem się do czasu okresowej niepłodności kobiecej. W działaniu takim nie ma niczego, co odbierałoby stosunkowi płciowemu właściwe mu odniesienie do rodzicielstwa, o ile wcześniej intencja małżonków była szczera i ocenili oni w duchu zasad odpowiedzialnego rodzicielstwa, że na obecnym etapie nie planują poczęcia. Nie ingerują oni w płodność zbliżenia, by świadomym działaniem uczynić niepłodnym akt płodny, lecz korzystają z okresowej niepłodności biologicznej. Nie niszczą zatem ani nie blokują dynamizmu rodzicielskiego wpisanego w akt miłości. Dlatego, jak zauważa Meissner, ,świadome i celowe zachowanie płciowego charakteru stosunku, podejmowanego $\mathrm{w}$ dniach fizjologicznej niepłodności, ma związek z poszanowaniem hierarchii wartości i może być właściwym wyrazem rodzicielskiego charakteru życia małżeńskiego i miłości małżeńskiej. Działanie takie jest zupełnym przeciwieństwem świadomego obezpłodnienia stosunku, który czynnie pozbawiony swojej płciowej treści, nie może być wyrazem płciowej miłości osób ludzkich" (Meissner 2012a, 53-54). Trzeba przy tym pamiętać, o czym już wspomniano wcześniej, że godziwość takiego działania zależy jeszcze od ważnego warunku, jakim jest nastawienie woli działających tu osób, które pozostają otwarte na rodzicielstwo i nie traktują okresowej wstrzemięźliwości jako sposobu do unikania potomstwa bez wystarczająco racjonalnych powodów (por. Meissner 2012a, 54), np. z wygody, niechęci do dziecka, błędnie ustawionych priorytetów życiowych. W przeciwnym razie, nawet przy zachowaniu okresowej wstrzemięźliwości, działanie takie uznać należałoby za antykoncepcyjne i złe moralnie, nie tyle z powodu fizycznej ingerencji w akt płciowy, która w tym przypadku nie ma miejsca, ale ze względu na wykluczenie świadomym aktem woli rodzicielskiego wymiaru zbliżenia cielesnego bez uzasadnionych powodów.

Myślenie powyższe wskazuje, że zastosowana przez Meissnera argumentacja przeciw antykoncepcji nie ma charakteru naturalistycznego, lecz na wskroś personalistyczny. W moralnej ocenie antykoncepcji uwzględnić należy nie tylko fakt celowego zaburzania rytmów płodności czy nawet niszczenia zdolności rozrodczej (działanie contra naturam), lecz ukryty w działaniu 
antykoncepcyjnym akt przeciw osobie (contra personam). Choć już pierwszy $\mathrm{z}$ argumentów jest bardzo doniosły i może dziś mógłby aspirować do rangi „argumentu ekologicznego”, to jednak zasługą Memoriału Krakowskiego jest uwypuklenie personalistycznej linii argumentacyjnej (por. Mielec 2013, 101). Zwraca ona uwagę na nie zawsze uświadomione nastawienie mentalne wykluczające pełnię daru osoby dla osoby, polegające na nieakceptacji płodności, która należy do istotnych wymiarów i zdolności ludzkich (jak ważna jest to zdolność dla osoby, można poznać np. w kontekście bolesnego doświadczenia niepłodności). Warto zauważyć, że argumentacja personalistyczna, wskazując na fakt wykluczenia $\mathrm{w}$ antykoncepcji zdolności prokreacyjnej przynależącej do osoby, chce podkreślić z innej perspektywy to, co teologia wyraża stwierdzeniem o rozerwaniu jednoczącego i prokreacyjnego wymiaru aktu seksualnego, które z woli Boga są nierozdzielne.

Wrażliwość personalistyczna pragnie uchronić argumentację etyczną przed błędem biologizmu. Nie ulega wątpliwości, że porządek natury musi być uszanowany, ale nie mniejszego szacunku domaga się osoba i porządek odniesień międzyosobowych. Stosowanie antykoncepcji niesie ze sobą następujący komunikat: nie chcę w tobie (lub/i w sobie) zdolności prokreacyjnej, dlatego ją eliminuję celowo podjętym działaniem. Innymi słowy: nie akceptuję ciebie (lub/i siebie) w tej pełni, jaką bytowo stanowimy (kocham cię, ale bez twojej płodności). Trudno zatem powiedzieć $\mathrm{w}$ takim przypadku o całkowitym przyjmowaniu i dawaniu się sobie wzajemnie, bez zastrzeżeń i wykluczeń, co przecież ma oznaczać akt miłosnego oddania w intymnym zbliżeniu. „Życie płciowe - podkreśla K. Meissner - powinno zawsze oznaczać i wyrażać w całej prawdzie wzajemny dar z siebie i miłość małżeńską, troskliwą o dobro drugiej osoby" (Meissner 2012b, 39). W działaniu antykoncepcyjnym dochodzi ostatecznie do zafałszowania miłości, gdyż podczas takiego współżycia nie może powstać komunia osób, brakuje całkowitego daru z siebie, nie ma pełnej afirmacji osoby, lecz akceptacja fragmentaryczna $z$ wykluczeniem ujmowanej osobowo zdolności prokreacyjnej (por. Meissner 2012b, 40).

$\mathrm{Z}$ zupełnie innym rodzajem działania mamy do czynienia w przypadku małżeńskiego współżycia podjętego w czasie okresowej niepłodności (por. Meissner 2012a, 53). Relacja małżonków wpisuje się wówczas w rytmy intymnego zbliżenia, w pełni akceptują oni siebie nawzajem i uznają specyfikę funkcjonowania cyklu płodności. Co więcej, pozostają otwarci na zrządzenia Bożej Opatrzności i zawsze są gotowi na przyjęcie daru życia. Wiedzą, że ostatecznie to Bóg jest jego dawcą, a rodzice życie przyjmują i współdziałają ze Stwórcą. Uzasadnione powody, rozumnie rozważone (zdrowotne, dobra dzieci, ekonomiczne), czynią decyzję powstrzymania się od poczęcia godziwą i podpowiadają podjęcie współżycia intymnego w okresie niepłodnym. Nie można jednak tymi samymi uzasadnionymi powodami tłumaczyć stosowania antykoncepcji 
(co czasem się zdarza), gdyż jej zło moralne nie zależy jedynie od intencji czy woli działających osób, lecz przede wszystkim od wewnętrznego przedmiotu czynu antykoncepcyjnego, który jest zły sam w sobie, będąc celowym działaniem odrywającym w zbliżeniu małżeńskim wymiar jednoczący od prokreacyjnego, co jest wyraźnym uderzeniem w sam Boży zamysł i logos stwórczy wpisany $\mathrm{w}$ istotę aktu płciowego, a także rani osobowy wymiar wzajemnego oddania, które przestaje być pełne i całkowicie afirmujące ukochaną osobę.

\section{Naturalna regulacja poczęć - twórcza harmonia natury i laski}

W świetle tego, co do tej pory zostało powiedziane o odpowiedzialnym rodzicielstwie oraz wymaganiach moralnych wynikających z godności osoby i sensu ludzkiej płciowości, uznać należy, że metoda okresowej wstrzemięźliwości jest godziwą moralnie i akceptowalną w świetle rozumu i wiary drogą planowania rodziny. W pełni też odpowiada chrześcijańskiemu powołaniu do świętości (por. Paweł VI 1968, 16; Meissner 2012a, 57).

Skutecznemu stosowaniu tej metody przychodzi z pomocą najpierw dobra edukacja tak kobiet, jak i mężczyzn, w zakresie poznania rytmu płodności oraz medycyna pozwalająca coraz precyzyjniej wyznaczać czas płodny i niepłodny. Już w latach sześćdziesiątych ubiegłego wieku z pełnym przekonaniem, włączając swój autorytet lekarski, Karol Meissner stwierdził: „Badania prowadzone przez licznych lekarzy od przeszło 60 lat, pozwoliły uchwycić zmiany towarzyszące w ustroju kobiety poszczególnym fazom cyklu płciowego" (Meissner 2012a, 52). Obserwacja tych zmian w zakresie temperatury ciała, struktury śluzu czy używanie coraz to nowocześniejszych dziś narzędzi diagnostycznych pozwala, zdaniem specjalistów, precyzyjnie określić dni płodne i niepłodne. Owszem, metoda okresowej wstrzemięźliwości wymaga wysiłku edukacyjnego i formacyjnego, lecz ani jedno, ani drugie nie jest czymś obcym człowiekowi. W wielu dziedzinach człowiek uczy się i formuje, niekiedy przez wiele lat. Dlaczego w dziedzinie przeżywania własnej płciowości miałaby unikać na wskroś personalistycznej drogi kształtowania swego człowieczeństwa i zastępować ją w pewnej mierze „kagańcowo-bezwolnym” narzędziem antykoncepcji?

Zdaniem Meissnera, które wyraził przeszło 50 lat temu, „rozporządzamy obecnie absolutnie nieszkodliwą i chętnie stosowaną, fizjologiczną metodą regulacji poczęć. Jest ona dostatecznie pewna, prosta i tania, by każda rodzina, mająca dobrą wolę i odpowiednio przeszkolona, mogła się nią posługiwać" (Meissner 2012a, 52).

Walory naturalnej regulacji poczęć ujawniają się jeszcze wyraźniej, gdy rozważy się dodatkowo kilka istotnych spraw rzutujących na całościową ocenę tej metody regulacji poczęć. 
Oprócz jej ekologiczności, darmowości, osobowego charakteru angażującego kobietę i mężczyznę, wysokiej skuteczności oraz gwarancji pokoju sumienia respektującego Boży zamysł wpisany w naturę aktu płciowego, nie można zapomnieć o bardzo istotnym wymiarze formacyjnym tej metody. Chodzi tu o zaangażowanie człowieka, który doskonali siebie w przeżywaniu sfery własnej seksualności i płciowości, która to sfera stanowi obszar licznych zranień i nadużyć. Niestety, ale to właśnie antykoncepcja, sprzyjając bezrefleksyjnemu i niedojrzałemu przeżywaniu seksualności, jest źródłem wielu frustracji i krzywd w relacjach międzyludzkich. Tymczasem właściwie stosowana naturalna regulacja poczęć, uwzględniając priorytetowe znaczenie miłości oblubieńczej, która ma charakter życiodajny i rodzicielski, pozwala odczytać głęboki sens aktu płciowego, chroniąc go przed banalizacją, która uderza ostatecznie w ludzi i ich intymne więzi.

Nie wolno zapominać, o czym wspomniał w swojej refleksji K. Meissner, że w sferze ludzkiej płciowości dają o sobie nieustannie znać różnego rodzaju skłonności do nieładu. Domagają się one nazwania oraz poddania świadomym działaniom formacyjnym, do których niewątpliwie należy ćwiczenie powściągliwości oraz cnoty czystości. Błędnym jest uleganie nieuzasadnionemu optymizmowi, „według którego każde pragnienie stosunku seksualnego w małżeństwie jest pragnieniem miłości” (Meissner 2012b, 41). Nie można także ulegać teologicznemu pesymizmowi podważającemu wiarę w to, że człowiek jest w stanie przezwyciężyć swoje słabości w sferze seksualnej. Wreszcie odrzucić należy jakiekolwiek zakusy legalizmu moralnego zaprzeczającego możliwości rozumnego poznania ładu moralnego wyrażonego w prawie naturalnym. W myśl tej pokusy - skoro nie istnieją żadne obiektywne przesłanki pozwalające stwierdzić nieład moralny w zakresie ludzkiej płciowości - wystarczyłoby tylko zmienić nauczanie Kościoła, a ludzie przestaliby grzeszyć. Takie naiwne i bardzo szkodliwe myślenie nie uwzględnia podstawowego faktu, iż nauczanie Kościoła w dziedzinie ludzkiej płciowości opiera się zarówno na objawionym zamyśle Bożym, jak i na dostępnych dla rozumu ludzkiego danych nauk o człowieku. Te ostatnie pozwalają odczytać autentyczny sens ludzkiej płciowości, poznać fenomen działania układu rozrodczego, jego wewnętrzny logos, i w człowieku wierzącym zrodzić przekonanie o niesprzeczności, czy wręcz spójności, tych danych z powołaniem mężczyzny i kobiety objawionym na kartach Pisma Świętego.

Wspomniany wyżej formacyjny wymiar naturalnej regulacji poczęć zakłada, że intymne zjednoczenie małżonków jest działaniem osobowym, czyli „powinno się stawać coraz bardziej rozumne, coraz bardziej wolne. Rozwój ten napotyka na przeszkody ze strony skłonności do nieładu, będącym skutkiem grzechu pierworodnego" (Meissner 2012b, 40). Stąd potrzeba włączenia sfery ludzkiej płciowości w szeroko rozumianą duchowość małżeńską, otwie- 
rania się na łaskę Bożą oraz aktywności w dziedzinie pracy nad sobą, aby coraz pełniej kierować popędem i panować nad nim. Na tym bowiem polega ludzkie, a tym bardziej chrześcijańskie przeżywanie seksualności i płciowości. Drogą chrześcijańskiego powołania do świętości podążają konkretne osoby, integrując mocą Bożej łaski cielesny, psychiczny i duchowy wymiar ludzkiej egzystencji ku pełni człowieczeństwa poznanego w Jezusie Chrystusie (por. Ef 4,13). To powołanie jest dla chrześcijan zasadniczym motywem przekraczania własnych słabości i wzajemnego umacniania się w dobrym. Relacja intymna kobiety i mężczyzny nie jest enklawą wyłączoną spod prawa miłości i dążenia do świętości. Człowiek zawsze będzie w dziedzinie płciowości doświadczał pewnego napięcia pomiędzy wymiarem doznaniowym (pociągająca przyjemność, upragniona rozkosz) a międzyosobowym i społecznym znaczeniem płciowości (odpowiedzialność za innych, za własne postępowanie). Karol Meissner uwrażliwia na fakt, że ,ilekroć międzyosobowe wartości zostają podporządkowane doznaniowej stronie współżycia płciowego, tylekroć działanie płciowe jest nieładem moralnym" (Meissner 2012b, 41). Koncentracja na szukaniu własnych doznań może skutecznie oddalać od prawdziwie miłosnego przeżycia zjednoczenia intymnego, gdyż odwraca uwagę od oczekiwań współmałżonki/ka, a prowadzi do skupienia na sobie. Takie ryzyko niesie w większym stopniu antykoncepcja niż naturalne planowanie rodziny uczące wstrzemięźliwości i powstrzymania się od współżycia ze względu na miłość. „W świadomym zaniechaniu działania płciowego mieścić się może daleko większy ładunek miłości - niż w samym działaniu" (Meissner 2012b, 41). Różne sytuacje życiowe mogą takiego zaniechania wymagać (choroba, okres przed i po porodzie, dłuższa rozłąka). Czasowe zaniechanie współżycia płciowego na pewno nie osłabi miłości, wręcz przeciwnie, wstrzemięźliwość podjęta z wyższych motywów może mieć większy wkład w miłość niż współżycie (por. Meissner 2012a, 56). Trochę na podobieństwo mądrego powiedzenia, że „mowa jest srebrem a milczenie złotem”. Z kolei antykoncepcja, przyzwyczajająca do otrzymywania rozkoszy na każde żądanie, na pewno nie sprzyja formowaniu postaw zdolnych do czasowego odroczenia satysfakcji płynącej z intymnego zjednoczenia. Rozwój osobowy człowieka i dążenie do chrześcijańskiej doskonałości wymagają wzrostu w rozumnym działaniu oraz coraz pełniejszej integracji władz wewnętrznych i zewnętrznych zachowań. Jak przypomni K. Meissner oznacza to, że „dążenia popędowe powinny zostać zintegrowane w rozumne działanie osoby. To jest droga prawdziwego rozwoju osoby. Natomiast nie można chyba określić mianem doskonalenia osoby celowego zapobiegania skutkom nieroztropnego, zdezintegrowanego działania" (Meissner 2012b, 42).

Wspomniana tu dezintegracja polegająca na oderwaniu współżycia intymnego od autentycznej miłości i rodzicielstwa skutkuje także tym, że mężczyźni 
i kobiety pozbawieni umiejętności panowania nad swoją seksualnością uciekają się do antykoncepcji, gdyż są bezradni, a nie chcą brać na siebie odpowiedzialności za skutki podejmowanego współżycia. W konsekwencji taka postawa może rodzić permanentny stan psychopatologiczny. Meissner stwierdza w tym kontekście, że „powszechnym zjawiskiem u osób stosujących praktyki antykoncepcyjne jest lęk przed dzieckiem, będący poważnym czynnikiem nerwicorodnym" (Meissner 2012a, 56). Obserwacje lekarskie i duszpasterskie dowiodły, że po przejściu na planowanie rodziny drogą okresowej wstrzemięźliwości objawy nerwicowe ustępują, pogłębia się więź małżeńska, a nawet pojawia się pragnienie dziecka. Tymczasem stosunki z antykoncepcją obciążone są w większym stopniu elementem frustracji wpływającym na psychikę małżonków (por. Meissner 2012a, 56-57).

\section{Podsumowanie i aktualizacja zagadnienia w perspektywie wiary}

Przywołane powyżej korzyści płynące ze stosowania naturalnej regulacji poczęć nie mogą jednak przysłonić ewentualnych wątpliwości czy obaw, jakie pojawiały się w dobie, gdy powstawał Memoriał Krakowski, i jakie wybrzmiewają również dzisiaj. Nie można przemilczeć doniosłych dylematów małżonków doświadczających problemu nieregularności cyklu owulacyjnego, tempa życia utrudniającego jego regularną obserwację, uwzględnić należałoby także różne przeciwwskazania medyczne dotyczące zajścia w ciążę. Jak wówczas mają postępować małżonkowie? Zadaniem teologów i katolickich lekarzy jest poszukiwanie takich rozwiązań, które nie będą stały w konflikcie z Bożą mądrością i miłością.

Ludzka kondycja moralna, ujawniająca się między innymi w sferze płciowości - pełna niepewności i kruchości - została ogarnięta przez Bożą miłość $\mathrm{i}$ jest nieustannie zbawiana: wzięta w Bożą opiekę. Bóg uzdalnia człowieka, aby poznał i podjął to, co po ludzku wydaje się, a może nawet jest, niemożliwe. Boża łaska włączona w ludzkie zaangażowanie dokonuje przemiany moralnych możliwości: człowiek wierzący może przekraczać siebie i wzrastać ku pełni Bożego zamysłu. To, co na początku drogi jawi się jako niemożliwe, z czasem okazuje się możliwe do osiągnięcia. Ta duchowa prawidłowość stała się podstawą do zastosowania w etyce katolickiej tzw. prawa stopniowości ${ }^{4}$.

${ }^{4}$ Zasada ta została przypomniana w adhortacji Familiaris consortio. Jan Paweł II tłumaczył ją następująco: „Porządek moralny, właśnie dlatego, że ujawnia i przedstawia zamysł Boży, nie może być czymś, co utrudnia życie człowiekowi i co nie odpowiada osobie; wręcz przeciwnie, odpowiadając najgłębszym potrzebom człowieka stworzonego przez Boga, służy jego pełnemu człowieczeństwu z tą samą subtelną i wiążącą miłością, z jaką sam Bóg pobudza, podtrzymuje i prowadzi do właściwego mu szczęścia każde stworzenie. [...] Także i małżonkowie, w zakresie swego życia 
Trzeba pamiętać o tym, że działanie antykoncepcyjne, przyjmując za cel przeszkodzenie w poczęciu dziecka i wbrew Bożemu zamysłowi odrywając wymiar prokreacyjny intymnego zbliżenia małżonków od jego wymiaru jednoczącego, jest w etyce katolickiej uznawane za czyn moralnie zły, gdyż ,nie wolno wziąć za przedmiot aktu woli tego, co ze swej istoty narusza ład moralny" (Paweł VI 1968, 14). Naruszenie tego ładu zachodzi także na płaszczyźnie interpersonalnych odniesień przez fakt nieakceptacji i celowego wykluczenia istotnej zdolności prokreacyjnej wpisanej w naturę osoby. W jednym z przemówień święty Jan Paweł II stwierdził: ,,antykoncepcję należy uważać obiektywnie za tak dogłębnie niegodziwą, że nigdy, dla żadnych racji nie może być usprawiedliwiona" (Jan Paweł II 1983, 23). Potwierdził to nauczanie współcześnie także papież Franciszek, gdy zdecydowanie potępił taką edukację seksualną, która zachęca do tzw. bezpiecznego seksu. Wyrażenie to, jego zdaniem, sugeruje ,negatywny stosunek do naturalnego prokreatywnego celu seksualności, tak jakby ewentualne dziecko było wrogiem, przed którym trzeba się bronić. W ten sposób krzewiona jest narcystyczna agresja a nie życzliwość" (Franciszek 2016, 283). Dlatego w innym miejscu tej samej adhortacji zachęca: „trzeba odkryć na nowo orędzie encykliki Humanae vitae Pawła VI, która podkreśla potrzebę poszanowania godności osoby przy moralnej ocenie sposobów regulacji urodzin" (Franciszek 2016, 82). Refleksja przedstawiona w niniejszym artykule wielokrotnie ukazywała, że antykoncepcja na pewno nie sprzyja poszanowaniu tej osobowej godności.

Porządek moralny zawierający m.in. normy negatywne, czyli zakazujące jakiegoś czynu, jest jednocześnie strażnikiem konkretnych dóbr, ważnych dla rozwoju osobowego człowieka (por. Jan Paweł II 1993, 79), które należy dostrzec i realizować. W przypadku antykoncepcji norma zakazująca - stając na straży ładu chcianego przez Boga, wpisanego w akt małżeński - chce wyeksponować ważne dobra: godność osoby, walor czystości, wartość wstrzemięźliwości, co wykazywał w Memoriale Krakowskim Karol Meissner. Naturalna regulacja poczęć daje możliwość uszanowania wszystkich tych wartości, liczy

moralnego, są powołani do ustawicznego postępu, wiedzeni szczerym i czynnym pragnieniem coraz lepszego poznawania wartości, które prawo Boże chroni i rozwija, oraz prostą i szlachetną wolą kierowania się nimi w konkretnych decyzjach. Nie mogą jednak patrzeć na prawo tylko jako na czysty ideał osiągalny w przyszłości, lecz powinni traktować je jako nakaz Chrystusa do wytrwałego przezwyciężania trudności. A zatem «tego, co nazywa się prawem stopniowości nie można utożsamiać ze stopniowościa prawa, jak gdyby w prawie Bożym miały istnieć różne stopnie i formy nakazu dla różnych osób i sytuacji. Wszyscy małżonkowie są powołani do świętości w małżeństwie według woli Boga, a to powołanie realizuje się w miarę, jak osoba ludzka potrafi odpowiedzieć na przykazanie Boże, ożywiona spokojną ufnością w łaskę Bożą i we własną wolę». Tak samo sprawą pedagogii Kościoła jest, by małżonkowie przede wszystkim jasno uznali naukę zawartą w Encyklice Humanae vitae, jako normatywną dla ich życia płciowego i szczerze usiłowali stworzyć warunki konieczne dla zachowania tych zasad". (Jan Paweł II 1981, 34). 
się z Bożą mądrością i miłością wyrażonymi w prawie moralnym, akceptuje porządek stworzenia i otwiera się na pomoc nadprzyrodzoną.

Chrześcijanie są wezwani nie tylko do unikania zła, ale przede wszystkim do czynienia dobra. Są przecież powołani do świętości. To powołanie powinno przyświecać im w codziennych zmaganiach przekraczania siebie i własnych ograniczeń - pojawiających się także na polu seksualności. Bywa, że wielu chrześcijan szuka dziś porady wśród opinii pochodzących z zsekularyzowanego świata. Tymczasem, jak przypomina św. Paweł, osoby wierzące nie mają brać wzoru z tego świata, lecz przemieniać się w myśleniu, szukając woli Bożej (por. Rz 12,3). Powołaniem chrześcijanina jest dążenie do świętości, a jej osiągnięcie jest możliwe z pomocą Bożej łaski, czyli tej przychylności Boga, który znając ludzkie niedomagania, lęki, obawy, wychodzi ku ludziom w swoim Synu. W Nim przywraca człowiekowi Boże dziecięctwo i miarę moralnych możliwości aż po heroiczną miłość. Nie od wszystkich Bóg zażąda heroizmu oddania życia, ale nie wymaga ponad miarę, gdy wzywa do czystości tych, których miłuje. Nie można zapominać, że Bóg zawsze umacnia człowieka do tego, czego od niego oczekuje.

\section{NATURAL REGULATION OF CONCEPTION AS AN EXPRESSION OF RE- SPONSIBLE PARENTHOOD. INTERDISCIPLINARY ARGUMENTATION OF FATHER KAROL MEISSNER IN THE MEMORIAE KRAKOWSKI}

\section{SUMMARY}

The article is dedicated to the arguments of father Karol Meissner in favor of promoting the natural regulation of conception in the context of preparations for the publication of the encyclical Humanae vitae. This argumentation was presented in a document known as the Memoriat Krakowski. It contains various texts written on the initiative of Karol Wojtyła by the Krakow theologians, ethics and doctors. The Memoriat Krakowski has not lost his relevance today. The value of this document is its personalistic approach and interdisciplinarity. Memoriat not only critically refers to contraception, but also promotes as an alternative natural regulation of conception supported by the theological, ethical and medical arguments cited in the document.

Keywords: contraception, Memoriat Krakowski, natural regulation of conception Slowa kluczowe: antykoncepcja, Memoriat Krakowski, naturalna regulacja poczęć 


\section{BIBLIOGRAFIA}

\section{Źródła}

Meissner, Karol. 2012a. Droga rozwiązania problemu odpowiedzialnego rodzicielstwa. W: Memoriał Krakowski. Uzasadnienie katolickiej nauki tyczacej podstaw moralnych życia matżeńskiego (Kraków 1968) oraz Wprowadzenie do encykliki „Humanae vitae” (Kraków 1969), red. Barbara Sadowska, 51-62. Poznań: BONAMI.

Meissner, Karol. 2012b. Odpowiedzialne rodzicielstwo. W: Memoriat Krakowski. Uzasadnienie katolickiej nauki tyczacej podstaw moralnych życia matżeńskiego (Kraków 1968) oraz Wprowadzenie do encykliki „Humanae vitae” (Kraków 1969), red. Barbara Sadowska, 34-50. Poznań: BONAMI.

\section{Opracowania}

Dziuba, Andrzej Franciszek. 1999. Drogi powstania i recepcji Humanae vitae. W: Człowiek. Miłość. Rodzina. Humanae vitae po 30 latach, red. Janusz Nagórny, Krzysztof Jeżyna, 17-83. Lublin: Redakcja Wydawnictw Katolickiego Uniwersytetu Lubelskiego.

Gałuszka, Paweł Stanisław. 2018. Karol Wojtyła i „Humanae vitae”. Wkład arcybiskupa krakowskiego i grupy polskich teologów w encyklikę Pawła VI. Warszawa: Muzeum Jana Pawła II i Prymasa Wyszyńskiego.

Kupczak, Jarosław. 2013. Teologiczna semantyka ptci. Kraków: WAM.

Mielec, Bogusław. 2013. Polskie tło encykliki Humanae vitae. W: Bioetyka pokolenia Karola Wojtyły - Jana Pawła II, red. Andrzej Muszala, Tomasz Kraj, Patrycja Zielonka-Rduch, 87-106. Kraków: Wydawnictwo św. Stanisława BM.

Semen, Yves. 2008. Seksualność wedlug Jana Pawła II, thum. Zofia Denkowska, Jakub Urbaniak. Poznań: Wydawnictwo Świętego Wojciecha.

\section{Magisterium Kościola:}

Franciszek. 2016. Adhortacja „Amoris laetitia”.

Franciszek. 2018. Adhortacja „Gaudete et exultate”.

Jan Paweł II. 1981. Adhortacja „Familiaris consortio”.

Jan Paweł II. 1983. Chrześcijańskie powołanie matżonków może wymagać także heroizmu.

Jan Paweł II. 1993. Encyklika , Veritatis splendor".

Paweł VI. 1968. Encyklika „Humanae vitae”.

Pius XII. 1951. Przemówienie do uczestniczek Kongresu Włoskiej Katolickiej Unii Położnych.

Pius XII. 1952. Przemówienie do uczestniczek Kongresu Światowej Unii Katolickich Stowarzyszeń Młodzieży Żeńskiej.

Maciej Olczyk - kapłan, dr hab. nauk teologicznych, specjalista teologii moralnej, profesor uczelni w Zakładzie Teologii Systematycznej w Uniwersytecie im. Adama Mickiewicza w Poznaniu, kontakt: donmatti@amu.edu.pl 